\title{
The Influence of Organic Solid Fertilizer Type and Liquid Organic Fertilizer Dose to The Yield of Cauliflower In Landslide-Prone Areas
}

\author{
Priyono $^{\text {a,** }}$, Rahayu ${ }^{\mathrm{b}}$, Slamet Minardi $i^{\mathrm{c}}$, Suntoro ${ }^{\mathrm{d}}$ \\ ${ }^{\mathrm{a}, \mathrm{b}}$ Agricultural Faculty of Slamet Riyadi University Surakarta; \\ ${ }^{\mathrm{c}, \mathrm{d}}$ Agricultural Faculty of Sebelas Maret University, Surakarta. \\ *Email: ir.priyono@gmail.com
}

\begin{abstract}
Cauliflowers are easy to grow as they can be planted all year round, regardless season and altitudes. They just need plenty of watering. The purpose of this research is to know the influence of best treatment of solid organic fertilizer (POP) and liquid organic fertilizer (POC) dosage to growth and yield of organic crop flower plant on soil in landslide prone area. This research method used Randomized Complete Basic Design (RAKL) with factorial experiment model consisting of 2 treatment factors, the first factor is Kind of Organic Solid Fertilizer (K) in the form of: cow manure $(\mathrm{Ks})$ / polybag; Goat manure $(\mathrm{Kb}) /$ polybag; Compost fertilizer (Kk) / polybag). The second factor is Dosage of liquid organic fertilizer in the form of: $0.0 \mathrm{cc} / 1$ / polybag; $15 \mathrm{cc} / 1$ / polybag, $30 \mathrm{cc} / 1 /$ polybag, $45 \mathrm{cc} / 1$ / polybag, then combined to 12 treatment combinations ( $\mathrm{KsC} 0, \mathrm{KsC} 1, \mathrm{KsC} 2, \mathrm{KsC} 3, \mathrm{KbC} 0, \mathrm{KbC} 1, \mathrm{KbC} 2, \mathrm{KbC} 3$, $\mathrm{KkC} 0, \mathrm{KkC1}, \mathrm{KkC} 2, \mathrm{KkC} 3$ ), then each treatment combination was repeated 3 times, finally obtained a total of 36 treatment combinations. Place of study in Green House Faculty of Agriculture UNISRI Surakarta with Andosol soil. The results of the research are: Pumping of organic fertilizer (interaction of POP type of POC fertilizer) significantly increase the growth and the result from all parameters such as height of place, number of leaves, leaf area, root length, flower diameter, wet weight and dry weight cauliflower; Whereas each treatment of POP type and POC dosage still significantly increases the growth and yield of Cauliflower although the parameters are slightly different for POP types there are 5 parameters (place height, leaf area, flower diameter, wet weight and bungakol dry weight) and POC fertilizer There are 4 parameters (number of leaves, leaf area, wet weight and dry weight of cauliflower), also reinforced by landslideprone land that is still relatively good for limitted planting, but not recomended for use continuously.
\end{abstract}

Keywords: Solid and liquid organic fertilizer, Organic Cauliflower, Landslide prone

\section{Introduction}

Vegetable plants including cauliflower in Indonesia have become the basic needs of people's life, because it is very useful for their life and freshness of the environment, this is indicated by the increasing awareness of the nutritional needs of the community so that it can lead to increased demand for vegetables including cauliflower

Therefore it is necessary to find a solution from an effective cultivation system by utilizing the agricultural sector's environmental resources, although on landslide-prone conditions that can improve yield and sustainability, are safe for public health and the environment in order to improve the welfare of farmers. One of the lands classified as landslide is Andosol. Andosol soil mostly occupy the slopes of volcanoes, usually with annual plant vegetation, annual crops, horticulture such as vegetables, fruits, flowers, even for medicinal plants.

Efforts towards that can be achieved by using solid and liquid organic fertilizers that are widely available on site, such as cow dung manure, goat manure, compost and Homemade liquid organic fertilizer (POC) or from the factory.

The special purpose of this research is to know the influence of the best treatment of solid organic fertilizer type(Pupuk Organik Padat - POP) and liquid organic fertilizer dose(Pupuk Organik Cair POC) to the growth and yield of organic cauliflower plants on soils in landslide prone areas. General purpose is to know the productivity level of cauliflower and landslide-prone areas too.

\section{Materials and Methods}

Completely Randomized Basic Design (CRBD). In factorial experiment model with 2 factors of treatment, the first factor is Organic Compound Fertilizer (K) which consists of 3 kinds, namely: Cow manure (Ks) / polybag; Goat manure $(\mathrm{Kb}) /$ polybag; Compost fertilizer (Kk)/ polybag. The second factor consists of 4 levels, namely: the dose of liquid organic fertilizer (C), each $0.0 \mathrm{cc} / 1 /$ polybag; $15 \mathrm{cc} / 1 /$ polybag, $30 \mathrm{cc} / 1 /$ polybag, $45 \mathrm{cc} / 1 /$ polybag, and combined treatment which results into 12 treatment combinations $(\mathrm{KsC} 0, \mathrm{KsC} 1, \mathrm{KsC} 2, \mathrm{KsC} 3$, $\mathrm{KbC} 0, \mathrm{KbC} 1, \mathrm{KbC} 2, \mathrm{KbC} 3, \mathrm{KkC0}, \mathrm{KkC} 1, \mathrm{KkC} 2, \mathrm{KkC} 3)$, then each treatment combination was repeated 3 times, so the total amounted to 36 treatment combinations.

Tools used: hoe, holder, scales, scissors, sifter, gembor, ruler, stationery, nameplate / banner, bucket, polybag $(30 \times 30 \mathrm{~cm})$, wrapping plastic $(10 \times 4 \mathrm{~cm})$, envelope wrapper, camera, oven. Materials used: Cauliflower seeds, solid organic fertilizer (cow dung, goat manure and compost), 
SNN (Super Natural Nutrition) organi organi (POC) fertilizer, top soil samples Andosol prone landslide Sub Das Samin from Guyon Village Tengklik, Tawangmangu Sub-district, Karanganyar District (Figures $1 \& 2$ ). The location of activities at Green House Agriculture Faculty Slamet Riyadi University Kadipira Sub Sub-District, Banjarsari Sub-district, Surakarta City is September 05 to November 18, 2016. Observation of research on each plant / polybag consists of: Number of leaves, leaf area, Root length, diameter (ø) flower, Fresh weight of flower, Dry weight of flower.

Test of Statistics and Evaluation of Results Analysis of the results (crop production) include: Duncan's continuous variation of $5 \%$ and $1 \%$ Duncan test and to determine the productivity level of bungakol plants used scoring model of inhibiting / obstacle factors in influencing bungakol plant production. Meanwhile, to determine the level of soil productivity (Andosol Prone to Landslide) used scoring elements of morphological, physics and soil chemistry that indicate the level of landslide vulnerability in affecting soil productivity. Furthermore, model of productivity relationship of cauliflower plant and Andosol land productivity prone to landslide.

\section{Result and Discussion}

The result of variance analysis which is clarified by Duncan 5\% test shows that the giving of solid organic fertilizer significantly increase plant height, leaf area, flower diameter, wet weight and dry weight of cauliflower shown by the most dominant influence of compost fertilizer Followed by the influence of cow dung manure on leaf area and wet weight and the effect of goat manure on flower diameter and dry weight (Table 1)

Table 1: Duncan Test Results Level 5\% Influence of Organic Solid Solid Fertilizer (POP) Against Growth And Cauliflower Yield 口

$\begin{array}{lccccccccc}\text { Type of } & \text { POP } & \text { Height } & \sum \text { Leaves } & \text { Area L } & \text { Roots } & \text { L } & \text { Flowers } & \text { Wet } & \text { W Dry W } \\ \text { Ks (Cow) } & 45.43 \mathrm{a} & 19.42 \mathrm{a} & 166.55 \mathrm{~b} & 17.58 \mathrm{a} & 12.83 \mathrm{a} & 157.93 \mathrm{~b} & 132.33 \mathrm{a} \\ \mathrm{Kk}(\mathrm{Kbg}) & 44.52 \mathrm{a} & 19.25 \mathrm{a} & 160.93 \mathrm{a} & 16.67 \mathrm{a} & 16.7 \mathrm{~b} & 133.5 \mathrm{a} & 138.65 \mathrm{~b} \\ \mathrm{Kk}(\mathrm{Kps}) & 48 \mathrm{~b} & 17.76 \mathrm{a} & 171.45 \mathrm{c} & 17.75 \mathrm{a} & 23.85 \mathrm{~b} & 160.75 \mathrm{~b} & 165.33 \mathrm{c} & \end{array}$

Description: Duncan test results followed by the same letter between treatments on each of the parameters above show no significant different.

The highest increase by compost fertilizer is thought to be caused by the higher and higher content and more available of the nutrition (made from mixture of animal dung + bekatul + sugar) than cow manure and goat / sheep manure, also reinforced by landslide-prone land characteristic for planting. Isdarmanto (2009) states, that the increased productivity of metabolism will increase the nutrient and water needs in the period of growth and development. Specifically in increasing leaf area and wet

Table 2: Duncan Test Result Level 5\% Effect of SNA Organic Fertilizer Dose (POC) Against Growth And Cauliflower Yield

口

\begin{tabular}{lccccccc} 
Dose of POC & Height & \multicolumn{2}{c}{$\Sigma$ Leaves } & Area L & \multicolumn{2}{c}{ Roots L $ø$ Flowers } & \multicolumn{2}{c}{ Wet W Dry W } \\
C0 $(0 \mathrm{ml})$ & $42.13 \mathrm{a}$ & $23.44 \mathrm{~b}$ & $145.5 \mathrm{a}$ & $17.57 \mathrm{a}$ & $17.13 \mathrm{a}$ & $153.33 \mathrm{~b}$ & $121.87 \mathrm{a}$ \\
$\mathrm{C} 1(15 \mathrm{ml})$ & $46.77 \mathrm{a}$ & $16.78 \mathrm{a}$ & $153.46 \mathrm{~b}$ & $18.87 \mathrm{a}$ & $16.33 \mathrm{a}$ & $153.8 \mathrm{~b}$ & $156.47 \mathrm{c}$ \\
$\mathrm{C} 2(30 \mathrm{ml})$ & $46.37 \mathrm{a}$ & $18.22 \mathrm{a}$ & $172.2 \mathrm{c}$ & $14.57 \mathrm{a}$ & $17.33 \mathrm{a}$ & $156.67 \mathrm{~b}$ & $154.17 \mathrm{~b}$ \\
C3 $(45 \mathrm{ml})$ & $46.53 \mathrm{a}$ & $19.33 \mathrm{a}$ & $194.67 \mathrm{~d}$ & $18.23 \mathrm{a}$ & $20.67 \mathrm{a}$ & $140 \mathrm{a}$ & $149.3 \mathrm{~b}$
\end{tabular}

Description: The numbers followed by the same letter from the Duncan 5\% test result between the treatments on each of the above parameters show no significant difference.

use of fertilizer ( $30 \mathrm{ml} /$ plant), also reinforced by the landslide-prone nature Which is still relatively good for planting. So here despite the limited availability of water due to hot weather (dry season), the process of photosynthesis normally still can use light energy efficiently and effectively for the growth of leaf area compared with the growth of other parameters (plant height, number of leaves, root length, Flower diameter, wet weight and dry weight). According to Darjanto and Satifah (1990), the vegetative phase shift to generative can be influenced by genotypes and external factors such as temperature, water, light and fertilizer. Related to this Kelik (2010) states, that the leaf area parameters have given an idea of the process and rate of photosynthesis in a plant shown in the formation of biomass. addition to the effect of the addition of water derived from the corresponding POC liquid form even though the dose given exceeds the recommended dosage as directed by the 
Confirmed Ratna (2002), that the increase in leaf area is the effort of plants in the effectiveness and efficiency of the capture of solar energy to perform photosynthesis normally.
The effect of interaction treatment of solid organic fertilizer (POP) and SNN organic fertilizer (POC) to observed parameters are listed in table 3 below.

Table 3: Duncan Test Results Level 5\% Influence Interaction Kinds of Solid Organic Fertilizer (POP) and Liquid Organic Fertilizer (POC) SNN Against Growth And Cauliflower Yields

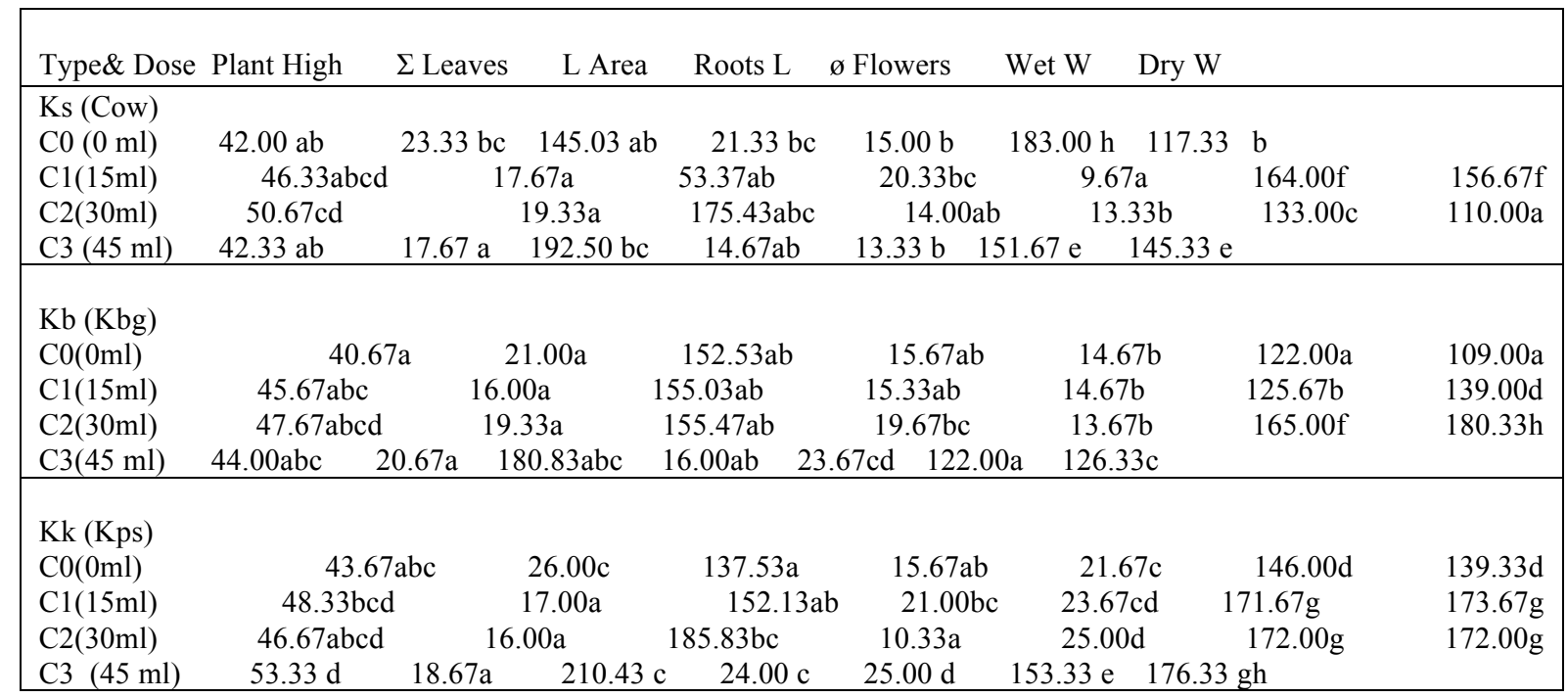

Description: The numbers followed by the same letter from the Duncan 5\% test results between the treatments on each of the parameters above show no significant difference

Result of analysis of variety (sidik ragam) which is clarified by result of Duncan $5 \%$ test indicate that interaction of solid organic fertilizer (POP) type and dosage of SNN Organic Fertilizer (POC) significantly increase to all parameters ie plant height, leaf number, leaf area, Length of root, flower diameter, wet weight and dry weight of cauliflower, this indicates that nutrient content and doses given from the fertilizer (POP and POC) according to the life activity needs of cauliflower plants, especially shown by the influence of fertilizer and compost fertilizer The most dominant organic SNN (POC) of SNN ( $\mathrm{KkC} 2$ for leaf area, $\mathrm{KkC} 3$ for dry weight, $\mathrm{KkC1}$ for root length and flower diameter) continued to be followed by the interaction effect of cow manure and SNN organic fertilizer (POC) $\mathrm{K} 1 \mathrm{D} 2$ for plant height, $\mathrm{KkC0}$ for The number of leaves and wet weight, also supported by the nature of landslide-prone lands that are still relatively good but very limited for certain crops, such as bungakol for limited alley cropping. It is reminiscent of: 1) the high rainy season has an impact on the inhibition of photosynthesis and nutrient washing process, especially cationation Alkaline substances, soil nutrient content (soil reaction is more acidic, nutrient content $\mathrm{N}, \mathrm{P}, \mathrm{K}$, cation exchange capacity (CEC), and saturation bases are all low, 2) low doses of fertilizer, and 3) easy soil properties (prone ) Landslides can significantly lower soil productivity (Table 4). As a result, doses of solid organic fertilizers are increasing but can not affect the significant increase of plant growth and yield, in addition to the low yield status (= $5-7$ tons / ha) or still below the average yield of RI in 2009 of 8,088 tons / ha (DG of Ministry of Horticulture, 2015). Harjowigeno (1987) suggests that plant growth is influenced by various factors, ie sunlight, temperature, air, water, and soil nutrient content such as $\mathrm{N}, \mathrm{P}, \mathrm{K}, \mathrm{Ca}, \mathrm{Mg}$ and others so that still relatively good for planting.
Further detail has been said, that the availability of nutrients can be affected by soil reaction $(\mathrm{pH})$, cation exchange capacity (KTK or CEC) and basic saturation (KB) (Foth, HD and LMTurk, 1972; Soepardi, 1979; and Harjowigeno , 1987). In addition, Harjowigeno (1987) and Lingga and Marsono (2001) stated that nitrogen nutrient has an important role in stimulating vegetative growth of plants, especially stems, branches and leaves. So if the element of nitrogen is available enough in the soil can increase the protein of plants and the more rapidly also change the systematic carbohydrates into protoplasm which plays an important role in improving the growth and development of crops.However vice versa if the nitrogen is in small amounts in the soil, hampered the formation of carbohydrates And proteins can consequently inhibit vegetative growth such as stems, branches and leaves.

Then Prawiranata et al. (1981) has explained that the dry weight of the whole body of the plant shows the nutrient status of the plant in the form of organic matter produced which depends on the rate of photosynthesis and respiration so that the increasing dry weight of the whole body of the plant (including berangkasan) shows good vegetative growth Or vice versa if the rate of photosynthesis and respiration are inhibited will result in poorly run vegetative growth (whole plant body weight is low). Landslide is a movement of soil mass that descends or exits the slopes due to disturbance of the stability of the soil mass / slope forming rocks along with the earth gravity. The trigger factor of the landslide involves adding heavy loads to the slope, sharpening the slope, excavation or cutting the slope, Water, changes in the position of river water / dams, decreases of slope resistance, and vibration or earthquakes (Hardiyatmo, 2006). So the mass of lost / destroyed rocks can be layers of soil (fertile / infertile), rock layers, and regolit (Tim Bejis Project, 2005; BGS, 2011; Couture, 2011; Geoscience Australia, 2011). 
If the relationship of crop productivity and soil productivity are listed in tables $4 \& 5$. The relationship of crop productivity and land productivity is very important and close, because interrelations can occur if the plants absorb un-surin in the soil will reduce the productivity of the soil, but if Low soil productivity will not necessarily decrease crop productivity

So if the low or high productivity of the plant will still decrease the productivity of the soil, otherwise low soil productivity is not necessarily (likely / may decrease crop productivity). But in table $4 \& 5$ there is a very close relationship and influence each other, But the average productivity score on the cauliflower plant (8.32) is lower than the average soil productivity score of Andosol prone to landslides (8.36), so that the plant is not so more affected by the soil andosol properties that are easily avalanche / subsidence than vice versa if the cauliflower plant in affecting the productivity of the andosol soil, so that the plant can grow and get yield so good.

Table 4: Results of Geomorphological, Physical, Soil Chemistry for Determination of Landslide Classification of Andosol Soil Lands in Guyon Village. Tengklik, Tawangmangu, Karanganyar

\begin{tabular}{|c|c|c|c|c|c|c|c|c|c|}
\hline \multicolumn{3}{|c|}{ Characteristic Geomorfologi } & \multicolumn{3}{|c|}{ Characteristic Physic } & \multicolumn{3}{|c|}{ Characteristic Chemistry } & \multirow{2}{*}{$\begin{array}{l}\text { Cate } \\
\text { gory }\end{array}$} \\
\hline $\begin{array}{l}\text { Properties } \\
\text { element }\end{array}$ & Actually & $\begin{array}{l}\text { Sc } \\
\text { ore } \\
1\end{array}$ & $\begin{array}{l}\text { Properties } \\
\text { element }\end{array}$ & Actual ly & $\begin{array}{l}\text { Sco } \\
\text { re }^{1}\end{array}$ & $\begin{array}{c}\text { Propert ies } \\
\text { element }\end{array}$ & $\begin{array}{l}\text { Actual } \\
\text { ly }\end{array}$ & $\begin{array}{l}\text { Sco } \\
\mathrm{re}^{1}\end{array}$ & \\
\hline $\begin{array}{l}\text { Climate } \\
\text { Type } \\
\text { Oldeman }\end{array}$ & $\mathrm{B}$ & 8 & Texture & Loam & 8 & $\begin{array}{l}\text { Soil } \\
\text { reaction }\end{array}$ & $\begin{array}{l}\text { Acid } \\
\text { rather }\end{array}$ & 8 & $\begin{array}{l}\text { D } \\
\mathbf{U} \\
\mathbf{C}\end{array}$ \\
\hline $\begin{array}{l}\text { Rainfall } \\
(\mathrm{mm} / \mathrm{th})\end{array}$ & $2000-3000$ & 8 & Structur & Crumb, blocky & 8 & $\mathrm{CEC}$ & Height & 8 & $\begin{array}{l}\mathbf{T} \\
\mathbf{I}\end{array}$ \\
\hline Relief & Wavy to hilly & 10 & Drainage & $\begin{array}{l}\text { Moderate rather } \\
\text { quick }\end{array}$ & 8 & $\begin{array}{l}\text { Base } \\
\text { saturation }\end{array}$ & $\begin{array}{l}\text { Very } \\
\text { Low }\end{array}$ & 8 & V \\
\hline Slope $(\%)$ & $40 \%$ & 10 & Permeability & Moderate & 8 & C-org & $\begin{array}{l}\text { Moder } \\
\text { ate }\end{array}$ & 8 & $\begin{array}{l}\mathbf{T} \\
\mathbf{Y}\end{array}$ \\
\hline Litologi & Andesit & 10 & Consisten cy & Friable, Firm & 8 & $\mathrm{~N}$ total & $\begin{array}{l}\text { Moder } \\
\text { ate }\end{array}$ & 8 & $\mathbf{S}$ \\
\hline Land use & Dry land & 8 & Color & $\begin{array}{|ll|}\text { Black, } & \text { reddy } \\
\text { Chocolat } & \\
\end{array}$ & 8 & $\mathrm{P} 2 \mathrm{O} 5$ & Low & 8 & $\begin{array}{l}\text { O } \\
\text { I }\end{array}$ \\
\hline Excavat ion & Moder ate & 6 & Roots & Micro, moderate & 10 & $\mathrm{~K}+$ & $\begin{array}{l}\text { Very } \\
\text { Low }\end{array}$ & 8 & $\mathbf{L}$ \\
\hline Vegetation & $\begin{array}{l}\text { Banana, } \\
\text { lamtoro, } \\
\text { vegetables }\end{array}$ & 8 & & & & $\mathrm{Ca}+$ & $\begin{array}{l}\text { Modera } \\
\text { te }\end{array}$ & 8 & $\begin{array}{l}\mathbf{P} \\
\mathbf{R} \\
\mathbf{O}\end{array}$ \\
\hline $\begin{array}{l}\text { Landslide } \\
\text { Potension }\end{array}$ & $\begin{array}{l}\text { Almost every } \\
\text { year }\end{array}$ & 10 & & & & $\mathrm{Mg}+$ & Low & 8 & $\begin{array}{l}\mathbf{N} \\
\mathbf{E}\end{array}$ \\
\hline $\begin{array}{l}\text { Landslide } \\
\text { type }\end{array}$ & $\begin{array}{l}\text { Subsidence \& } \\
\text { Slump }\end{array}$ & 10 & & & & $\begin{array}{c}\text { Organic } \\
\text { matter }\end{array}$ & $\begin{array}{l}\text { Modera } \\
\text { te }\end{array}$ & 8 & $\mathbf{L}$ \\
\hline & Score & 88 & & ore & 58 & $\Sigma$ Score & & 80 & $\begin{array}{l}\mathbf{A} \\
\mathbf{N}\end{array}$ \\
\hline CAULIFLC & WER YIELD & & LOW & \begin{tabular}{|l} 
CAULIFLOWE \\
PRODUCTIVIT
\end{tabular} & & & OW & $\geq 8$ & $\begin{array}{l}\text { D } \\
\text { S } \\
\text { L } \\
I \\
\text { D } \\
\text { E } \\
(8.36 \\
\text { or } \\
\geq 8) \\
\end{array}$ \\
\hline
\end{tabular}

1) Scores of Insecurity / Constraints: 2-4-6-8-10 = Very Low-Low-Moderate-High-Very High

Total Score $=88+58+80+8=284$ so the average score $=234: 28=8.36$

$\left.{ }^{2}\right)$ Andosol prone to landslide categories namely: Low $=$ Average Constraint Score $=8.36(>8=$ high $)=$ low productivity of Andosol prone to landslide

It appears from Table $4 \& 5$ above that yields / productivity of cauliflower plants and soil productivity of landslide-prone Andosol are all low, mainly by the effects of high rainfall, bumpy reliefs to the hills with high cliffs, rather sharp slopes, lots of land use (moor ) With seasonal crops, moderate soil excavation, almost (often) every rainy season has occurred landslide, frequent movement / vibration of the real land. So the land of Andosol here is relatively severe condition (especially landslide and its chemical nature is rather acidic and poor nutrients), so it is not suitable for planting especially seasonal crops in the long run (Fig. 2 \& 3). 
Table 5: Geomorphology, Physical, Soil Chemistry and Biomass Element, as well as Determining Category of Occurrence / Constraints on Cauliflower Yield on Andosol Ground in Guyon Village, Tengklik, Tawangmangu, Karanganyar

\begin{tabular}{|c|c|c|c|c|c|c|c|c|c|c|c|c|}
\hline \multicolumn{3}{|c|}{ Characteristic Geomorfologi } & \multicolumn{3}{|c|}{ Characteristic Physic } & \multicolumn{3}{|c|}{$\begin{array}{l}\text { Characteristic } \\
\text { Chemistry }\end{array}$} & \multicolumn{2}{|c|}{$\begin{array}{l}\text { Characteristic } \\
\text { Solution }\end{array}$} & \multirow{2}{*}{$\begin{array}{l}\text { resul } \\
\begin{array}{l}\text { Sco } \\
\text { re }^{1}\end{array}\end{array}$} & \multirow{5}{*}{\begin{tabular}{|l} 
Categor \\
$\mathrm{y}^{2}$ \\
$\mathbf{C}$ \\
$\mathbf{A}$ \\
$\mathbf{U}$ \\
$\mathbf{L}$ \\
$\mathbf{I}$ \\
$\mathbf{F}$ \\
$\mathbf{L}$ \\
$\mathbf{O}$ \\
$\mathbf{W}$ \\
$\mathbf{E}$ \\
$\mathbf{R}$
\end{tabular}} \\
\hline $\begin{array}{l}\text { Properties } \\
\text { element }\end{array}$ & Actually & $\begin{array}{l}\text { Scor } \\
\mathrm{e}^{1}\end{array}$ & $\begin{array}{l}\text { Propertie } \\
\text { s element }\end{array}$ & Actual ly & $\begin{array}{l}\text { Sco } \\
\text { re }^{1}\end{array}$ & $\begin{array}{l}\text { Propert } \\
\text { ies } \\
\text { element }\end{array}$ & $\begin{array}{l}\text { Actual } \\
\text { ly }\end{array}$ & $\begin{array}{l}\text { Sco } \\
\text { re }^{1}\end{array}$ & $\begin{array}{l}\text { Properti } \\
\text { es } \\
\text { elemen }\end{array}$ & $\begin{array}{l}\text { Actual } \\
\text { ly }\end{array}$ & & \\
\hline $\begin{array}{l}\text { Climate } \\
\text { Type } \\
\text { Oldeman }\end{array}$ & B & 8 & Texture & Loam & 6 & $\begin{array}{l}\text { Soil } \\
\text { reaction }\end{array}$ & $\begin{array}{l}\text { Acid } \\
\text { rather }\end{array}$ & 8 & $\begin{array}{l}\text { Plant } \\
\text { height }\end{array}$ & Low & 10 & \\
\hline $\begin{array}{l}\text { Rainfall } \\
(\mathrm{mm} / \mathrm{th})\end{array}$ & $\begin{array}{l}2000- \\
3000\end{array}$ & 8 & Structur & $\begin{array}{l}\text { Crumb, } \\
\text { locky }\end{array}$ & 6 & $\mathrm{CEC}$ & Height & 2 & $\Sigma$ leaf & Low & 10 & \\
\hline Relief & $\begin{array}{l}\text { Wavy to } \\
\text { hilly }\end{array}$ & 10 & Drainage & $\begin{array}{l}\text { Moderate } \\
\text { rather } \\
\text { quick }\end{array}$ & 6 & $\begin{array}{l}\text { Base } \\
\text { saturation }\end{array}$ & $\begin{array}{l}\text { Very } \\
\text { Low }\end{array}$ & 8 & $\begin{array}{l}\text { Leaf } \\
\text { areas }\end{array}$ & Low & 10 & \\
\hline Slope (\%) & $40 \%$ & 10 & $\begin{array}{l}\text { Permeabil } \\
\text { ity }\end{array}$ & $\begin{array}{l}\text { Moderat } \\
\mathrm{e}\end{array}$ & 8 & C-org & $\begin{array}{l}\text { Modera } \\
\text { te }\end{array}$ & 8 & $\begin{array}{c}\text { Roots } \\
\text { lenght }\end{array}$ & Low & 10 & \\
\hline Litologi & Andesit & 10 & $\begin{array}{l}\text { Consisten } \\
\text { cy }\end{array}$ & \begin{tabular}{|l} 
Friable, \\
Firm
\end{tabular} & 8 & $\mathrm{~N}$ total & $\begin{array}{l}\text { modera } \\
\text { te }\end{array}$ & 8 & $\varnothing$ flower & Low & 10 & $\mathbf{P}$ \\
\hline Land use & Dry land & 8 & Color & $\begin{array}{l}\text { 3lack, } \\
\text { reddy } \\
\text { Chocolat }\end{array}$ & 8 & $\mathrm{P} 2 \mathrm{O} 5$ & Low & 8 & $\begin{array}{l}\text { Fresh } \\
\text { weight }\end{array}$ & Low & 10 & $\begin{array}{l}\text { O } \\
\text { D } \\
\mathbf{U}\end{array}$ \\
\hline Excavat ion & $\begin{array}{l}\text { Moder } \\
\text { ate }\end{array}$ & 6 & Roots & $\begin{array}{l}\text { Micro, } \\
\text { noderate }\end{array}$ & 6 & $\mathrm{~K}+$ & $\begin{array}{l}\text { Very } \\
\text { Low }\end{array}$ & 10 & $\begin{array}{l}\text { Dry } \\
\text { weight }\end{array}$ & Low & 10 & \\
\hline $\begin{array}{l}\text { Vegetatio } \\
\mathrm{n}\end{array}$ & $\begin{array}{l}\text { Banana, } \\
\text { lamtoro, } \\
\text { vegetable } \\
\text { s }\end{array}$ & 8 & & & & $\mathrm{Ca}+$ & $\begin{array}{l}\text { moder } \\
\text { ate }\end{array}$ & 8 & Solar & Low & 10 & $\begin{array}{l}\text { I } \\
\text { V } \\
\text { I } \\
\text { T }\end{array}$ \\
\hline $\begin{array}{l}\text { Landslide } \\
\text { Potension }\end{array}$ & \begin{tabular}{|l|} 
Almost \\
every \\
year \\
\end{tabular} & 10 & & & & $\mathrm{Mg}+$ & Low & 10 & Humidi ty & Hight & 6 & $\begin{array}{l}Y \\
(8.32\end{array}$ \\
\hline $\begin{array}{l}\text { Landslide } \\
\text { type }\end{array}$ & $\begin{array}{l}\text { Subsiden } \\
\text { ce \& } \\
\text { Slump }\end{array}$ & 10 & & & & $\begin{array}{r}\text { Organic } \\
\text { matter }\end{array}$ & $\begin{array}{l}\text { Moder } \\
\text { ate }\end{array}$ & 8 & & & & $\begin{array}{l}\text { or } \\
\geq 8 \text { ) }\end{array}$ \\
\hline$\Sigma$ Score & & 88 & $\sum$ Score & & 48 & $\Sigma$ Score & & 78 & & & 86 & \\
\hline $\begin{array}{c}\text { THE LEV } \\
\text { ANDOSO }\end{array}$ & $\begin{array}{l}\text { EL OF L } \\
\text { SOIL }\end{array}$ & NDS & PRC & NE FOR & $\begin{array}{l}\mathbf{V P} \\
= \\
\mathbf{V H} \\
\end{array}$ & SOIL PF & ODUCT & IVIT & & LOW & $\geq 8$ & \\
\hline
\end{tabular}

1) Scores of Insecurity / Constraints: 2-4-6-8-10 = Very Low-Low- Moderate-High-Very High

Total Score $=88+48+78+86+8=308$ so the average score $=340 / 37=8.32$

${ }^{2}$ ) Cauliflower yield categories namely: Low $=$ Average Constraint Score $=\mathbf{8 . 3 2}(>\mathbf{8}=$ high $)=$ low productivity of cauliflower; VP $=$ Very Prone; VH $=$ Very High

\section{Conclusion}

Organic fertilizers, such as solid fertilizer (POP), doses of liquid fertilizer (POC) and their interactions significantly increase growth especially when viewed from the parameters used such as height of place, leaf area, flower diameter, wet weight and dry weight of cauliflower, also strengthened By the nature of landslides prone to landslides that are still relatively good but very limited for certain crops, such as cauliflower for limited alley plants (Alley cropping limited. planting) Then the details are as follows:

1. Solid Organic Fertilizer (POP) type significantly increase plant height, leaf area, flower diameter, wet weight and dry weight of cauliflower. The best results of compost fertilizer $(\mathrm{Kk})$.

2. Dosage of liquid organic fertilizer (POC) SNN significantly influence on leaf number, leaf area, wet weight and dry weight of cauliflower. The best results are $1.5 \mathrm{ml} /$ plant $(\mathrm{C} 1)$.

3. The interaction of solid organic fertilizer (POP) type and the dosage of liquid organic fertilizer (POC) of SNN significantly increase to all parameters ie plant height, leaf number, leaf area, root length, flower diameter, wet weight and dry weight of cauliflower.
The best results are KKC3 (Compost and POC $4.5 \mathrm{ml}$ / plant) or $\mathrm{KkC} 2$ (compost and $\mathrm{POC} 3.0 \mathrm{ml} /$ plant dosage) alternatives.

4. The productivity level for crops and soils Andosol prone to landslides is low, so the soil is unsuitable or not recommended for continuous use of cauliflower plants (seasonal).

\section{Acknowledgment}

Thank you to the Promoter Team who until now finished later on the instructions and guidance, namely: 1.Prof. Dr. Ir. H. Suntoro, M.S. (Promoter); 2.Prof. Dr. Ir. H. Slamet Minardi, M.P (Co Promotor 1); 3.Dr. Sc. Agr. Rahayu, S.P., M.P (Co Promotor 2).

\section{References}

[1] Anonymous. 1993. Commercial Vegetables. The Swadaya spreader. Jakarta.

[2] Arief, Arifin. 1990. Horticulture. Andy Offset. Yogyakarta.

[3] Balitbangtan. (2012). Technical Guidance of Soil, Plant, Water and Fertilizer Analysis ed.2, Bogor, Balitanah Kementan 
[4] Balitbangtan. (2012). Technical Guidelines for Land Evaluation for Agricultural Commodities.ed.revisi 2011, Bogor, BB Litbang and SLP, Kementan RI.

[5] Balitbangtan. (2014). Technical Guidance of National Soil Classification.ed.1 / 2014, Bogor, BB Litbang and SLP, Kementan RI.

[6] BGS. (2011).Landslide Assesment.Natural Environment Research Council. Geo Reports. Mam Tor Derbyshire UK.

[7] Cahyono, Bambang. 1995. How to Improve the Cultivation of Cabbage. D),. Yogyakarta, Nusatama Library.

[8] Couture, R.,(2011). Landslide Terminology Nasional Technical Guidelines and Best Practices on Landslides. Geological Survey of Canada of Canada Open File 6824, $12 \mathrm{p}$.

[9] Directorate General of Horticulture. (2015). Horticultural Production Statistics 2014.Jakarta, Balitbangtan.Kementan RI.

[10] Foth, H.D. and L.M.Turk (1972). Fundamentals of Soil Science. 5ed. USA, John Wiley \& Sons, Inc.

[11] Geoscience Australia. (2011). Hazard Risk and Impact Analysis. Australian Goverment.http://www.ga.gov.au/hazards/risk-and-impactanalysis.html.

[12] Hardiyatmo, H.C., 2006. Landslide Handling and Erosion.1ed. Yogyakarta, Gajah Mada University Press.

[13] Harjowigeno, S. (1987). Geology. Ed.1.Jakarta, Mediyatama Sarana Perkasa.

[14] Harjowigeno, S. \& Widiatmaka. (2011). Evaluation of Land Suitability \& Land Use Planning. Yogyakarta, GM University Press.

[15] Kesbanglinmas Office. 2009. Map of Disaster Area Kab.Karanganyar. Karanganyar, Karanganyar regency.

[16] Karama U.S. 1990. Use of fertilizer in agricultural production. Paper at Seminar Puslitbang Tanaman Pangan, 4 August 1999 in Bogor.
[17] Kartasapoetra, G. Kartasapoetra, AG. M. M. Sutedjo. 1987. Soil and Water Conservation. Jakarta, Bina Aksara.

[18] Laksono, B.J. 2011. Cultivation Opportunity of Cauliflower and Broccoli in Kab. Batanghari. Http://yusufsilatumbuhan.blogspot.com/2011/10/kembang-kolbrokoli.html

[19] Lingga and Marsono (2001). Fertilizer Use Instructions, Jakarta, Penebar Swadaya.

[20] Musnawar, E.I. 2004 Liquid and Solid Organic Fertilizer, Maker, Application, Self-Spreader, Jakarta.

[21] Munir, M. 1996. Main Land of Indonesia. Characteristics, Classification, and Utilization .. Jakarta, Pustaka Jaya.

[22] Nazaruddin. (2000). Cultivation and Arrangement of Lowland Vegetables. Jakarta, Penebar Swadaya.

[23] Prawiranata, W. Said Hasan and P Tjondronegoro, (1981). Fundamentals of Plant Physiology, Volume II, Bogor, Faculty of Agriculture IPB.

[24] Priyono. (2015). Landslide Classification, Landslide Classification Classification, Classification of Landslide Farm Prone. ECHO. ISSN: 0215-3092. Th.XXVII / 49 / Agt.2014-Jan.2015, 1602-1617, Surakarta, LP3M UNIBA.

[25] Soepardi, G .; 1979. Nature and Land Character I \& II. Bogor, IPB. [26] Team Bejis Project. (2005). Identification of Landslide Potential and Efforts to Prevent Landslide Hazards. Report of Bejis Projoject Ausaid. Unibraw-Bappedal Cooperation Project Prov. Jatim-Pemkab. Malang-Australian Manage Contractor.

[26] Team Bejis Project. (2005). Identification of Landslide Potential and Efforts to Prevent Landslide Hazards. Report of Bejis Projoject Ausaid. Unibraw-Bappedal Cooperation Project Prov. Jatim-Pemkab. Malang-Australian Manage Contractor. 